Yüzüncü Yil Üniversitesi
Tarim Bilimleri Dergisi

Araştırma Makalesi (Research Article)

Effects of Cadmium and Zinc Applied to the Soil Enriched with Sewage Sludge on Plant Growth and Antioxidative Enzyme Activity of Lettuce (Lactuca sativa L. var. longifolia)

\author{
Ayşegül BITTIKTAŞ ${ }^{1}$, Sibel BOYSAN CANAL ${ }^{2 *}$, Mehmet Ali BOZKURT ${ }^{2}$ \\ ${ }^{1}$ Tusba Chamber of Agriculture, Van, Turkey \\ ${ }^{2}$ VanYüzüncü Y1l University, Faculty of Agriculture, Department of Soil Science and Plant Nutrition, Van, \\ Turkey \\ *Sorumlu yazar e-posta:sibelboysan@hotmail.com
}

\section{Makale Bilgileri}

Recivied: 06.09.2019

Accepted: 08.12.2019

Online Published 31.12.2019

DOI: $10.29133 /$ yyutbd.616417

\section{Keywords}

Antioxidative enzymes, Cadmium,

Lettuce (Lactuca sativa $\mathrm{L}$. var. longifolia),

Zinc.

\begin{abstract}
The aim of this study is to investigate the effects of a constant rate of sewage sludge (SS) together with cadmium (Cd) and zinc ( $\mathrm{Zn}$ ) at varying levels on the growth of lettuce and antioxidative enzyme activity. In the pot experiment, a fixed ratio of $10 \% \mathrm{SS}$ with varying doses of $\mathrm{Cd}\left(\mathrm{Cd} 1: 50 \mathrm{mg} \mathrm{Cd} \mathrm{kg}^{-1} ; \mathrm{Cd} 2: 100\right.$

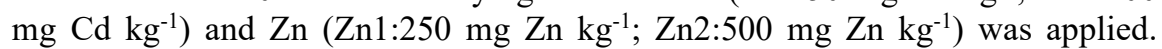
According to experiment results, compared to the control, $10 \% \mathrm{SS}+\mathrm{Cd} 1$ and $10 \% \mathrm{SS}+\mathrm{Cd} 2$ applications significantly reduced fresh and dry shoot weights, plant height, $\mathrm{Zn}$ content and SOD (superoxide dismutase) enzyme activity in the root and shoot of lettuce. However, $10 \% \mathrm{SS}+\mathrm{Cd} 1$ and $10 \% \mathrm{SS}+\mathrm{Cd} 2$ applications significantly increased shoot and root Cd contents, GPX (glutathione peroxidase) enzyme activity in plant and the amount of $\mathrm{Cd}$ in soil. On the other hand, $10 \% \mathrm{SS}+\mathrm{Zn} 1+\mathrm{Cd} 1$ application increased fresh shoot weight, $\mathrm{Zn}$ content, SOD and GPX enzyme activities in the shoot of lettuce and decreased the amount of DTPA-Cd in comparison with $10 \% \mathrm{SS}+\mathrm{Cd} 1$ application. Compared to the $\mathrm{Cd} 1$ application, $10 \% \mathrm{SS}+\mathrm{Zn} 2+\mathrm{Cd} 1$ application increased SOD and GPX enzyme activities in the root of lettuce. In comparison with $10 \% \mathrm{SS}+\mathrm{Cd} 2$ application, $10 \% \mathrm{SS}+\mathrm{Zn} 2+\mathrm{Cd} 2$ application increased fresh and dry shoot weight, Zn content, SOD and GPX enzymes in both shoot and root of lettuce and decreased shoot $\mathrm{Cd}$ content and the amount of DTPA-Cd in soil. These results indicate that the $\mathrm{Zn}$ application could be beneficial for reducing the toxic effects of $\mathrm{Cd}$ in lettuce.
\end{abstract}

\title{
Arıtma Çamuru ile Zenginleştirilmiş Toprağa Uygulanan Kadmiyum ve Çinkonun Marulun (Lactuca sativa L. var. longifolia) Gelişimi ve Antioksidatif Enzim Aktivitesine Etkisi
}

\section{Article Info}

Geliș: 06.09.2019

Kabul: 08.12.2019

Online Yayınlama 31.12.2019

DOI: 10.29133 /yyutbd. 616417

Anahtar kelimeler Antioksidatif enzimler,

Kadmium,

Marul (Lactuca sativa L. var.

longifolia),

Çinko,
Öz: Bu çalışmanın amacı sabit oranda arıtma çamuru ile birlikte kadmiyum ve çinko düzeylerinin marul bitkisinin gelişimine ve antioksidatif enzim aktivitesine etkisini araştırmaktır. Saksı çalı̧̧masında sabit oranda, arıtma çamuru (\%10AÇ), değişen oranlarda kadmiyum $\left(\mathrm{Cd} 1: 50 \mathrm{mg} \mathrm{Cd} \mathrm{kg}^{-1} ; \mathrm{Cd} 2: 100 \mathrm{mg} \mathrm{Cd} \mathrm{kg}^{-1}\right)$ ve çinko (Zn1:250 mg Zn kg-1; Zn2:500 mg Zn kg ${ }^{-1}$ ) uygulanmıştır. Elde edilen sonuçlara göre, $\% 10 \mathrm{AÇ}+\mathrm{Cd} 1$ ve $\% 10 \mathrm{AÇ}+\mathrm{Cd} 2$ uygulamaları, kontrole göre, marul bitkisinin kuru ve yaş sürgün ağırlığını, bitki boyu, çinko içeriğini ve kök ve sürgün bölgesinde SOD (süperoksit dismutaz) enzim aktivitesini önemli düzeyde azaltmıştır. Bununla birlikte marul bitkisinin kök ve sürgün kısımlarında ve toprakta kadmiyum konsantrasyonu ile GPX (glutatyon peroksidaz) enzim aktivitesi önemli düzeyde artış göstermiştir. Ancak $10 \% \mathrm{AÇ}+\mathrm{Zn} 1+\mathrm{Cd} 1$ uygulaması ile $10 \% \mathrm{ACC}+\mathrm{Cd} 1$ karşılaştırıldığında, marulun sürgün kısımlarında 
SOD ve GPX enzim aktiviteleri, çinko içeriği ve sürgün yaş ağırlığında artışa neden olurken toprakta DTPA-Cd (yarayışl1-Cd) içeriğinde düşüşe neden olmuştur. $10 \% \mathrm{ACC}+\mathrm{Zn} 2+\mathrm{Cd} 1$ uygulaması ile $10 \% \mathrm{AÇ}+\mathrm{Cd} 1$ karşılaştırıldığında, marul kök bölgesinde GPX ve SOD enzim aktiviteleri artış göstermiştir. 10\%AÇ $+\mathrm{Zn} 2+\mathrm{Cd} 2$ uygulaması ile $10 \% \mathrm{AÇ}+\mathrm{Cd} 2$ karşılaştırıldığında bitkinin sürgün yaş ve kuru ağırlığı, $Z n$ içeriğinde ve hem kök hem sürgün SOD ve GPX enzim aktivitesinde artışa neden olurken sürgün $\mathrm{Cd}$ içeriğinde ve toprak DTPA-Cd (yarayışl1-Cd) içeriğinde düşüşe neden olmuştur. Bu sonuçlar göstermektedir ki, marul bitkisinde çinko uygulaması kadmiyum toksisitesini azaltmada faydalı olabilir.

\section{Introduction}

Cadmium (Cd) is a non-essential and toxic heavy metal (Grant et al., 1998). Cd is very easily taken up by plant roots and accumulates in plants due to its much more mobile nature relative to other heavy metals. Various crops such as lettuce and spinach, grown in heavy metal polluted soils accumulate large amounts of $\mathrm{Cd}$. This causes heavy metals to join the food chain (Monterio et al., 2009). Cd causes visible symptoms such as browning of roots, necrosis, chlorosis and slow growth in many plant species (Gülser and Sönmez, 2012; Tran and Popova, 2013). Cd has been found to induce oxidative stress in cells leading to the accumulation of reactive oxygen species (ROS) (Liu et al., 2008). Plant cell which is exposed to $\mathrm{Cd}$ stress activates enzymatic defence mechanism including superoxide dismutase (SOD), glutathione-S-transferase (GST), catalase (CAT), ascorbate peroxidase (APX) and glutathione reductase (GR) (Hana et.al., 2008; Monterio et al., 2009; Lin and Aarts, 2012; Viehweger, 2014).

Zinc $(\mathrm{Zn})$ is an essential micronutrient for plants due to a component of many enzymes needed for the normal development of plants (Aravind et al., 2005). $\mathrm{Zn}$ ions in soil lessen the effects of $\mathrm{Cd}$ toxicity by reducing $\mathrm{Cd}$ uptake (Köleli et al., 2004). In lettuce and spinach, $\mathrm{Zn}$ has a synergistic interaction with $\mathrm{Cd}$ at the root surface (Kabata-Pendias and Pendias, 1984). However many studies show that the relationship between $\mathrm{Zn}$ and $\mathrm{Cd}$ is antagonistic because both elements have overlapping features (Rizwan et al., 2017). Zn helps the reduction of Cd concentration both in plants and in soil solution (Saifullah et al., 2014). Mckenna et al. (1993) reported that $\mathrm{Zn}$ application reduces the accumulation of $\mathrm{Cd}$ in roots and transportation of $\mathrm{Cd}$ from roots to young leaves in lettuce and spinach. The relationship between $\mathrm{Cd}$ and $\mathrm{Zn}$ depends heavily on plant type, tissue type and cadmium and zinc concentration (Zhao et al., 2011). Zn has an important role in the anti-oxidative defence system against the destructive effects of reactive oxygen species. $\mathrm{Zn}$ is a necessary metal component of key enzymes such as Cu-Zn SOD, APX, and GR (Cakmak, 2000; Wu and Zhang, 2002). Zn application improves growth and yield in wheat grown in Cd-contaminated soil (Abbas et al., 2017). Rizwan et al. (2017) reported that foliar application of Zn-lysine (Zn-lys) complex decreased Cd contents as well as reduced the oxidative stress in wheat.

Sewage sludge (SS) contains high levels of heavy metal. Heavy metal toxicity is an important factor in limiting agricultural production. In this case, the source of the SS is important. However, the application of SS results in an increase in organic matter, nitrogen, phosphorus and microbiological activity in the soil (Castro et al., 2009). Erdogan et al. (2011) reported that the SS application increased heavy metal concentration in ornamental plants. Hossain et al. (2015) reported that compared to biochar and sewage sludge, biochar application reduced the accumulation of heavy metals in cherry tomatoes. Although SS is a source of heavy metals, it is an important organic complex that controls the solubility of heavy metals, due to its high organic matter content.

The aim of this study is to investigate the effects of $\mathrm{Cd}$ and $\mathrm{Zn}$ in the soil added with SS on plant development and antioxidative enzyme activity in lettuce. We also investigated Cd solubility in soil and preventive effects of $\mathrm{Zn}$ application to mitigate $\mathrm{Cd}$ toxicity in lettuce. 


\section{Materials and Methods}

\subsection{Characterization of soil and SS}

The soil used in the experiment was taken from the experimental area of the Faculty of Agriculture of Van Yüzüncü Y1l University. The soil characteristics are presented in Table 1. The experiment soil was characterized by alkaline $\mathrm{pH}$, unsalted, medium calcareous, low organic matter and low nitrogen. SS was taken from the Van Municipality Wastewater Treatment Plant. $\mathrm{Cd}, \mathrm{Pb}, \mathrm{Cu}$ and $\mathrm{Zn}$ contents in SS were under the threshold values recommended in the soil pollution control guideline (Anonymous, 2010) (Table 1).

Table 1 Characteristics of soil and SS

\begin{tabular}{|c|c|c|c|}
\hline & Units & Soil & SS \\
\hline Texture & & Sandy Clay Loam & \\
\hline $\mathrm{pH}(1 / 2.5)$ & & 8.42 & 6.91 \\
\hline Salt, & $\mathrm{dS} / \mathrm{m}$ & 0.10 & 1.0 \\
\hline Lime, & $\%$ & 12.22 & - \\
\hline Organic Material, & $\%$ & 1.97 & 27.4 \\
\hline Total N & $\%$ & 0.095 & 1.42 \\
\hline Available $\mathrm{P}$ & $\mathrm{mg} / \mathrm{kg}$ & 7.1 & \\
\hline Extractable with DTPA & $\mathrm{mg} / \mathrm{kg}$ & & \\
\hline $\mathrm{Fe}$ & $\mathrm{mg} / \mathrm{kg}$ & 9.18 & \\
\hline $\mathrm{Zn}$ & $\mathrm{mg} / \mathrm{kg}$ & 1.52 & \\
\hline $\mathrm{Cu}$ & $\mathrm{mg} / \mathrm{kg}$ & 0.72 & \\
\hline $\mathrm{Mn}$ & $\mathrm{mg} / \mathrm{kg}$ & 8.99 & \\
\hline $\mathrm{Cd}$ & $\mathrm{mg} / \mathrm{kg}$ & 0.01 & \\
\hline $\mathrm{Pb}$ & $\mathrm{mg} / \mathrm{kg}$ & 0.285 & \\
\hline Total elements & $\%$ & & \\
\hline $\mathrm{P}$ & $\%$ & - & 0.58 \\
\hline $\mathrm{K}$ & $\%$ & - & 0.19 \\
\hline $\mathrm{Fe}$ & $\%$ & - & 0.79 \\
\hline $\mathrm{Zn}$ & $\mathrm{mg} / \mathrm{kg}$ & - & 762 \\
\hline $\mathrm{Cu}$ & $\mathrm{mg} / \mathrm{kg}$ & - & 111 \\
\hline $\mathrm{Mn}$ & $\mathrm{mg} / \mathrm{kg}$ & - & 645 \\
\hline $\mathrm{Cd}$ & $\mathrm{mg} / \mathrm{kg}$ & - & 0.73 \\
\hline $\mathrm{Pb}$ & $\mathrm{mg} / \mathrm{kg}$ & - & 40.3 \\
\hline
\end{tabular}

\subsection{Pot experiment}

The pot experiment was carried out in the growth chamber in the Faculty of Agriculture, Van Yüzüncü Y1l University. The temperature of the growth chamber was set to $18 \pm 2^{0} \mathrm{C}$ because lettuce is a cool climate vegetable crop. In the present study, completely randomized design with fourreplication trial was carried out. After eight weeks of the development period, plant samples were taken from each parcel, both from the root and above-ground parts. In each application, 4 plots and 15 pots were formed in each parcel. Each pot was filled with $300 \mathrm{~g}$ soil and planted with 5 seeds. After germination, the seedling was checked and noted for 8 days. Dilution was made in the way that a plant remains in each pot. In the experiment, at a fixed ratio of $10 \% \mathrm{SS}$, two different levels of $\mathrm{Cd}$ and $\mathrm{Zn}$ were applied. These applications were $50 \mathrm{mg} \mathrm{Cd} \mathrm{kg}^{-1}, 100 \mathrm{mg} \mathrm{Cd} \mathrm{kg}^{-1}, 250 \mathrm{mg} \mathrm{Zn} \mathrm{kg}^{-1}$ and $500 \mathrm{mg} \mathrm{Zn}$ $\mathrm{kg}^{-1}$. Ten applications consisted of combinations of $\mathrm{SS}, \mathrm{Cd}$, and $\mathrm{Zn}$ are as follows:

1-. Control 2- 10\% (SS) 3-10\%SS+Cd1: $50 \mathrm{mg} \mathrm{Cd} \mathrm{kg}-14-10 \% \mathrm{SS}+\mathrm{Cd} 2: 100 \mathrm{mg} \mathrm{Cd} \mathrm{kg}{ }^{-1} 5-10 \% \mathrm{SS}$ +Zn1: $250 \mathrm{mg} \mathrm{Zn} \mathrm{kg}{ }^{-1} 6-10 \% \mathrm{SS}+\mathrm{Zn} 2: 500 \mathrm{mg} \mathrm{Zn} \mathrm{kg}^{-1} 7-10 \% \mathrm{SS}+\mathrm{Zn} 1+\mathrm{Cd} 1 \quad 8-10 \% \mathrm{SS}+\mathrm{Zn} 1+\mathrm{Cd} 2$ 9$10 \% \mathrm{SS}+\mathrm{Zn} 2+\mathrm{Cd} 110-10 \% \mathrm{SS}+\mathrm{Zn} 2+\mathrm{Cd} 2$. 


\subsection{Chemical analyses of soil and SS}

The soil samples and SS were air-dried in a shadowy place and passed through a $2 \mathrm{~mm}$ sieve. In line with the guidelines, soil texture was determined by Bouyoucous hydrometer method (Bouyoucous, 1951). In 1:2.5 soil-water mixture and 1:5 SS-water mixture, $\mathrm{pH}$ was measured (Jackson, 1958). Lime content was calculated using Scheiblercalcimeter (H1zalan and Ünal, 1966). Soil organic matter was determined using Walkley Black method (Walkley, 1947). Total N was measured using the Kjeldahl method (Kacar, 1994). Available Fe, Cu, Zn, Mn, and Cd were extracted with DTPA and then measured using Atomic Absorption Spectrophotometer (AAS) technique (Kacar and Katkat, 1999). The amount of organic matter in SS was determined using the combustion method suggested by Kacar, 1994. Air-dried samples were digested with a mixture of $\mathrm{HNO}_{3}-\mathrm{HClO}_{4}$ acids and analysed for the concentration of $\mathrm{P}, \mathrm{K}, \mathrm{Fe}, \mathrm{Cd}, \mathrm{Pb} \mathrm{Fe}, \mathrm{Zn}, \mathrm{Cu}$, and $\mathrm{Mn}$ by using atomic absorption spectrophotometer (Kacar, 1994).

\subsection{Enzyme analysis in plant sample}

Enzymatic measurements were carried out at $4{ }^{0} \mathrm{C}$. Fresh samples $(1 \mathrm{~g})$ were homogenized in 6 $\mathrm{ml} \mathrm{0,1} \mathrm{M}$ potassium phosphate buffer $(\mathrm{pH}$ 7.0). After being homogenized, $200 \mathrm{mg}$ Polyvinylpolipidolidone (PVPP) and 0.1 M EDTA (Etilen diaminetetraacetic acid) was added. Homogenates taken into the tubes were centrifuged at $+4{ }^{\circ} \mathrm{C}$ at $21000 \mathrm{~g}$ for 15 minutes. The supernatant was used as a crude enzyme extract for SOD, GPX, GR, GSH enzyme analyses. Superoxide dismutase (SOD EC 1.15.1.1) activity was measured with calculating inhibition percentage of formazan formation using the Randox-Ransod enzyme kit at $505 \mathrm{~nm}$ spectrophotometrically (McCord and Fridovich, 1969). Glutathione-S-transferase (GST) was measured at $25^{\circ} \mathrm{C}$ spectrophotometrically by following the conjugation of glutathione with 1-chloro-2, 4-dinitrobenzene (CDNB) at $340 \mathrm{~nm}$ (Mannervik and Guthenberg, 1981). Glutathione peroxidase was measured by the Randox-Ransel enzyme kit at $340 \mathrm{~nm}$ using spectrophotometry (Shimadzu UV/VIS1201). This enzyme activity was determined by the change in absorbance values during the oxidation of nicotinamide adenine dinucleotide phosphate (NADPH) (Fhole and Günzler, 1984). GR was measured at $340 \mathrm{~nm}$ by following the oxidation of NADPH by GSSG, oxidized glutathione, (Beutler, 1984). CoStat software package was used for statistical analyses. Significant differences were determined by Duncan's Multiple Range tests (Düzgüneş et al., 1987).

\section{Results and Discussion}

\subsection{Plant growth}

The application of 10\% SS alone did not have a significant impact on shoot length, shoot fresh

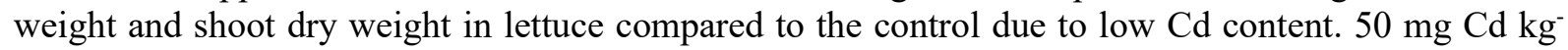
${ }^{1}(\mathrm{Cd} 1)$ and $100 \mathrm{mg} \mathrm{Cd} \mathrm{kg}^{-1}(\mathrm{Cd} 2)$ additions decreased shoot length, shoot fresh and dry weight compared to the control in lettuce (Table 2). Visual symptoms of Cd toxicity were necrotic areas spreading from the edges to centre in the oldest leaf in lettuce. Another symptom of $\mathrm{Cd}$ applications was a noticeable decline in biomass and development compared to the control (Figure1). In comparison with the control, $100 \mathrm{mg} \mathrm{Cd} \mathrm{kg}{ }^{-1}$ decreased root fresh and dry weight. It has been determined that $\mathrm{Cd}$ stress inhibits plant growth in various studies on different plant species (Benavides et al 2005). This may affect only young leaves, only old or both young and old leaves (Tran and Popova, 2013). $10 \% \mathrm{SS}+\mathrm{Zn} 2+\mathrm{Cd} 1$ and $10 \% \mathrm{SS}+\mathrm{Zn} 2+\mathrm{Cd} 2$ applications increased shoot length, shoot fresh and dry weight compared to $10 \% \mathrm{SS}+\mathrm{Cd} 1$ and $10 \% \mathrm{SS}+\mathrm{Cd} 2$ applications. However, $10 \% \mathrm{SS}+\mathrm{Zn} 1+\mathrm{Cd} 1$ and $10 \% \mathrm{SS}+\mathrm{Zn} 1+\mathrm{Cd} 2$ applications did not have a significant impact on the yield parameters in lettuce (Table 2). We found that high levels of $\mathrm{Zn}$ had significant positive effects on yield parameters of lettuce under Cd toxicity conditions in SS amended growth medium. 


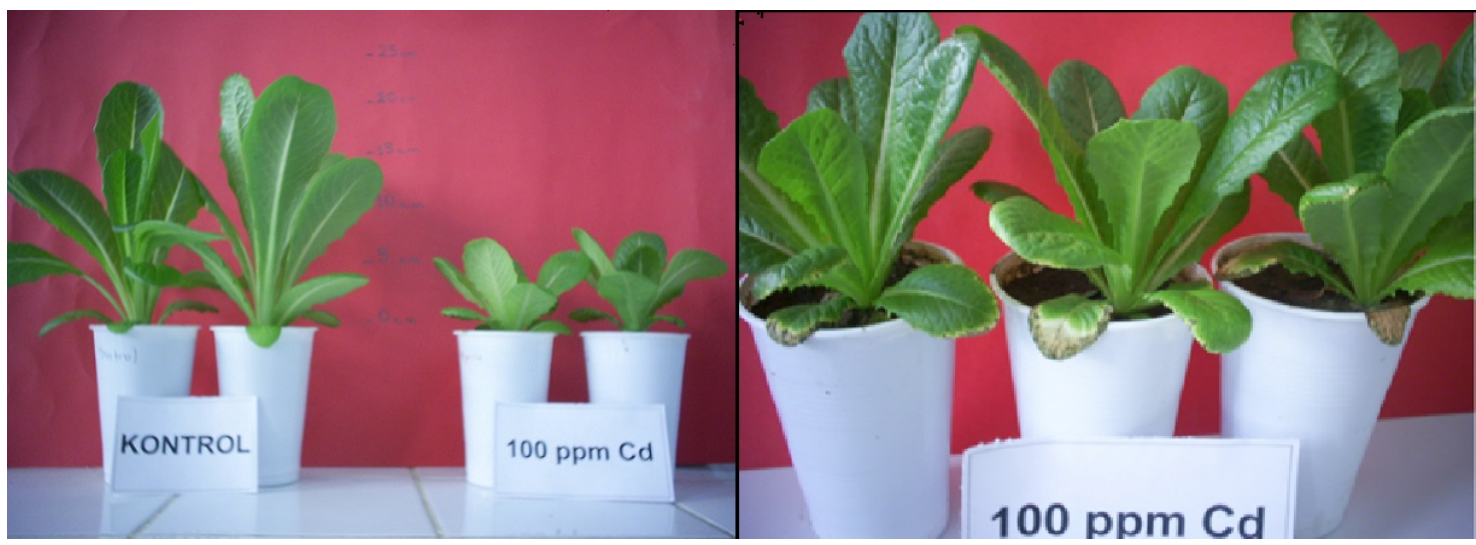

Figure1: Effects of, $100 \mathrm{mg} / \mathrm{kg} \mathrm{Cd}$ applications (right), $100 \mathrm{mg} \mathrm{kg}^{-1} \mathrm{Cd}$ and control applications (left) on the shoot of lettuce.

Hassan et al. (2005) identified that $\mathrm{Zn}$ applications increased growth in two rice cultivars under Cd toxicity. Wu and Zhang (2002) reported that the addition of $\mathrm{Zn}$ in Cd-contained solutions was related to an increase in shoot and root biomass relative to $\mathrm{Cd}$ alone treatment in barley.

Table 2. Effects of SS, Cd (50,100 mg kg-1) and Zn (250, $\left.500 \mathrm{mg} \mathrm{kg}^{-1}\right)$ applications on plant growth of lettuce.

\begin{tabular}{llllll}
\hline Applications & \multicolumn{1}{c}{$\begin{array}{c}\text { Shoot length } \\
(\mathrm{cm})\end{array}$} & $\begin{array}{c}\text { Shoot fresh } \\
\text { weight }(\mathrm{g} / \mathrm{pot})\end{array}$ & $\begin{array}{c}\text { Shoot dry weight } \\
(\mathrm{g} / \mathrm{pot})\end{array}$ & $\begin{array}{c}\text { Root fresh } \\
\text { weight }(\mathrm{g} / \mathrm{pot})\end{array}$ & $\begin{array}{c}\text { Root dry weight } \\
(\mathrm{g} / \text { pot })\end{array}$ \\
\hline Control & $16.90 \pm 1.60 \mathrm{~b}$ & $11.97 \pm 1.57 \mathrm{ab}$ & $0.75 \pm 0.045 \mathrm{~b}$ & $3.61 \pm 0.35 \mathrm{a}$ & $0.185 \pm 0.046 \mathrm{a}$ \\
$10 \% \mathrm{SS}$ & $17.11 \pm 1.84 \mathrm{~b}$ & $13.14 \pm 1.53 \mathrm{a}$ & $0.68 \pm 0.095 \mathrm{bc}$ & $2.31 \pm 0.36 \mathrm{~b}$ & $0.113 \pm 0.029 \mathrm{cde}$ \\
$10 \% \mathrm{SS}+\mathrm{Cd} 1$ & $12.70 \pm 0.64 \mathrm{~cd}$ & $8.62 \pm 1.78 \mathrm{c}$ & $0.50 \pm 0.105 \mathrm{de}$ & $3.25 \pm 0.61 \mathrm{a}$ & $0.165 \pm 0.021 \mathrm{ab}$ \\
$10 \% \mathrm{SS}+\mathrm{Cd} 2$ & $10.48 \pm 0.45 \mathrm{e}$ & $5.31 \pm 1.30 \mathrm{~d}$ & $0.37 \pm 0.027 \mathrm{e}$ & $2.31 \pm 0.53 \mathrm{~b}$ & $0.130 \pm 0.037 \mathrm{cde}$ \\
$10 \% \mathrm{SS}+\mathrm{Zn} 1$ & $17.57 \pm 1.39 \mathrm{~b}$ & $12.40 \pm 0.70 \mathrm{ab}$ & $0.64 \pm 0.050 \mathrm{bc}$ & $2.13 \pm 0.35 \mathrm{~b}$ & $0.108 \pm 0.022 \mathrm{e}$ \\
$10 \% \mathrm{SS}+\mathrm{Zn} 2$ & $18.26 \pm 1.49 \mathrm{ab}$ & $14.02 \pm 1.63 \mathrm{a}$ & $0.92 \pm 0.134 \mathrm{a}$ & $2.58 \pm 0.59 \mathrm{~b}$ & $0.147 \pm 0.028 \mathrm{bcd}$ \\
$10 \% \mathrm{SS}+\mathrm{Zn} 1+\mathrm{Cd} 1$ & $12.70 \pm 0.82 \mathrm{~cd}$ & $6.86 \pm 1.92 \mathrm{~d}$ & $0.45 \pm 0.027 \mathrm{e}$ & $2.02 \pm 0.38 \mathrm{~b}$ & $0.117 \pm 0.010 \mathrm{cde}$ \\
$10 \% \mathrm{SS}+\mathrm{Zn} 1+\mathrm{Cd} 2$ & $11.75 \pm 1.48 \mathrm{de}$ & $6.64 \pm 1.30 \mathrm{~d}$ & $0.38 \pm 0.053 \mathrm{e}$ & $2.10 \pm 0.079 \mathrm{~b}$ & $0.108 \pm 0.014 \mathrm{e}$ \\
$10 \% \mathrm{SS}+\mathrm{Zn} 2+\mathrm{Cd} 1$ & $19.61 \pm 0.82 \mathrm{a}$ & $13.77 \pm 2.86 \mathrm{a}$ & $0.70 \pm 0.146 \mathrm{bc}$ & $2.34 \pm 0.16 \mathrm{~b}$ & $0.112 \pm 0.013 \mathrm{de}$ \\
$10 \% \mathrm{SS}+\mathrm{Zn} 2+\mathrm{Cd} 2$ & $14.52 \pm 1.03 \mathrm{c}$ & $9.58 \pm 2.37 \mathrm{bc}$ & $0.60 \pm 0.042 \mathrm{~cd}$ & $2.52 \pm 0.55 \mathrm{~b}$ & $0.149 \pm 0.022 \mathrm{bc}$ \\
\hline
\end{tabular}

${ }^{*} \mathrm{a}, \mathrm{b}, \mathrm{c}, \mathrm{d}, \mathrm{e}$ : Statistically significant mean differences are indicated with different letters in the same column $(\mathrm{p}<0.05)$.

\subsection{Antioxidative enzyme activity in lettuce}

$10 \% \mathrm{SS}$ alone application did not change SOD, GST and GR enzymes activity in shoot and root compared to the control. However, $10 \% \mathrm{SS}+\mathrm{Cd} 1$ and $10 \% \mathrm{SS}+\mathrm{Cd} 2$ applications decreased SOD enzyme activity and increased GPX activity in shoot and root as compared to the control. $10 \% \mathrm{SS}$ $+\mathrm{Cd} 1+\mathrm{Zn} 1$ application increased SOD and GPX enzyme activity in shoot and increased GST and GR enzyme activity in root compared to Cd1 alone application (Table 3,4). In root $10 \% \mathrm{SS}+\mathrm{Zn} 2+\mathrm{Cd} 1$ application increased SOD and GPX enzymes activity compared to Cd1 alone (Table 4). $10 \%$ $\mathrm{SS}+\mathrm{Zn} 1+\mathrm{Cd} 2$ and $10 \% \mathrm{SS}+\mathrm{Zn} 2+\mathrm{Cd} 2$ applications increased SOD and GPX enzymes activity in shoot compared to $\mathrm{Cd} 2$ alone (Table 3). We found that applications did not result in a significant change of GST and GR enzyme activity but increased SOD and GPX enzyme activity in the shoot and root of lettuce plant. Jibril et al. (2017) reported that Cd toxicity may prevent cell in two different ways through binding to specific groups of proteins and lipids thus it may cause free radical formation inducing oxidative stress. At the same time, nutrient imbalances and reduction in the amount of vitamin $\mathrm{C}$ resulting from the toxic effect of $\mathrm{Cd}$ can alone trigger oxidative stress, nutrient deficiencies, and reduction in plant growth and development of agricultural crops. Plant cells activate anti-oxidative protection systems in motion to deal with the harmful effects of reactive oxygen species (Hana et al., 2008; Shahabivand and Aliloo, 2016). In a similar study, Cd treatment decreased SOD and CAT enzymes activity in bean (Phaseolus vulgaris) (Chaoui et al., 1997). However, Cherif et al. (2011) 
found that Cd application increased SOD enzyme activity whereas APX, GR enzyme activity decreased in tomato plants.

Table 3. Effects of SS, Cd (50, $\left.100 \mathrm{mg} \mathrm{kg}^{-1}\right)$ and $\mathrm{Zn}\left(250,500 \mathrm{mg} \mathrm{kg}^{-1}\right)$ applications on anti-oxidative enzyme activities in the shoot of lettuce.

\begin{tabular}{llcll}
\hline & \multicolumn{4}{c}{ Shoot $\left(\mathrm{U} \mathrm{g}^{-1}\right.$ tissue $)$} \\
\hline Applications & \multicolumn{1}{c}{ SOD } & GST & GR & GPX \\
\hline Control & $867 \pm 15.45 \mathrm{bc}$ & $0.177 \pm 0.046 \mathrm{a}$ & $0.174 \pm 0.013 \mathrm{a}$ & $1858 \pm 124 \mathrm{e}$ \\
$10 \% \mathrm{SS}$ & $873 \pm 4.97 \mathrm{abcde}$ & $0.161 \pm 0.042 \mathrm{a}$ & $0.127 \pm 0.046 \mathrm{ab}$ & $7052 \pm 512 \mathrm{ab}$ \\
$10 \% \mathrm{SS}+\mathrm{Cd} 1$ & $837 \pm 16.59 \mathrm{~d}$ & $0.162 \pm 0.017 \mathrm{a}$ & $0.129 \pm 0.028 \mathrm{ab}$ & $4427 \pm 1176 \mathrm{~cd}$ \\
$10 \% \mathrm{SS}+\mathrm{Cd} 2$ & $836 \pm 10.39 \mathrm{~d}$ & $0.154 \pm 0.013 \mathrm{a}$ & $0.131 \pm 0.050 \mathrm{ab}$ & $4015 \pm 488 \mathrm{~d}$ \\
$10 \% \mathrm{SS}+\mathrm{Zn} 1$ & $875 \pm 2.22 \mathrm{ab}$ & $0.177 \pm 0.031 \mathrm{a}$ & $0.108 \pm 0.036 \mathrm{~b}$ & $5921 \pm 876 \mathrm{bcd}$ \\
$10 \% \mathrm{SS}+\mathrm{Zn} 2$ & $881 \pm 1.26 \mathrm{a}$ & $0.151 \pm 0.017 \mathrm{a}$ & $0.098 \pm 0.017 \mathrm{~b}$ & $7148 \pm 2603 \mathrm{ab}$ \\
$10 \% \mathrm{SS}+\mathrm{Zn} 1+\mathrm{Cd} 1$ & $881 \pm 1.26 \mathrm{a}$ & $0.186 \pm 0.020 \mathrm{a}$ & $0.104 \pm 0.025 \mathrm{~b}$ & $7956 \pm 2071 \mathrm{ab}$ \\
$10 \% \mathrm{SS}+\mathrm{Zn} 1+\mathrm{Cd} 2$ & $861 \pm 3.65 \mathrm{c}$ & $0.190 \pm 0.005 \mathrm{a}$ & $0.118 \pm 0.027 \mathrm{~b}$ & $6550 \pm 1989 \mathrm{bc}$ \\
$10 \% \mathrm{SS}+\mathrm{Zn} 2+\mathrm{Cd} 1$ & $878 \pm 3.40 \mathrm{ab}$ & $0.164 \pm 0.025 \mathrm{a}$ & $0.125 \pm 0.030 \mathrm{ab}$ & $9063 \pm 1743 \mathrm{a}$ \\
$10 \% \mathrm{SS}+\mathrm{Zn} 2+\mathrm{Cd} 2$ & $876 \pm 2.50 \mathrm{ab}$ & $0.174 \pm 0.029 \mathrm{a}$ & $0.123 \pm 0.025 \mathrm{~b}$ & $6540 \pm 597 \mathrm{bc}$ \\
\hline
\end{tabular}

${ }^{*}$ a,b,c,d,e: Statistically significant mean differences are indicated with different letters in the same column $(\mathrm{p}<0.05)$.

Table 4. Effects of SS, Cd (50, $\left.100 \mathrm{mg} \mathrm{kg}^{-1}\right)$ and $\mathrm{Zn}\left(250,500 \mathrm{mg} \mathrm{kg}^{-1}\right)$ applications on anti-oxidative enzyme activities in the root of lettuce

\begin{tabular}{lllll}
\hline & \multicolumn{4}{c}{ Root $\left(\mathrm{U} \mathrm{g}^{-1}\right.$ tissue $)$} \\
\hline Applications & \multicolumn{1}{c}{ SOD } & \multicolumn{1}{c}{ GST } & \multicolumn{1}{c}{ GR } & \multicolumn{1}{c}{ GPX } \\
\hline Control & $832 \pm 9.43 \mathrm{a}$ & $0.115 \pm 0.012 \mathrm{e}$ & $0.038 \pm 0.007 \mathrm{~cd}$ & $287 \pm 102 \mathrm{e}$ \\
$10 \% \mathrm{SS}$ & $831 \pm 20.82 \mathrm{a}$ & $0.144 \pm 0.023 \mathrm{de}$ & $0.035 \pm 0.007 \mathrm{~d}$ & $422 \pm 119 \mathrm{e}$ \\
$10 \% \mathrm{SS}+\mathrm{Cd} 1$ & $739 \pm 19.55 \mathrm{c}$ & $0.164 \pm 0.049 \mathrm{bcde}$ & $0.045 \pm 0.013 \mathrm{bcd}$ & $1723 \pm 255 \mathrm{bc}$ \\
$10 \% \mathrm{SS}+\mathrm{Cd} 2$ & $753 \pm 31.35 \mathrm{~d}$ & $0.158 \pm 0.016 \mathrm{cde}$ & $0.056 \pm 0.011 \mathrm{ab}$ & $1759 \pm 92.6 \mathrm{bc}$ \\
$10 \% \mathrm{SS}+\mathrm{Zn} 1$ & $834 \pm 11.84 \mathrm{a}$ & $0.128 \pm 0.020 \mathrm{e}$ & $0.042 \pm 0.004 \mathrm{bcd}$ & $455 \pm 89.4 \mathrm{e}$ \\
$10 \% \mathrm{SS}+\mathrm{Zn} 2$ & $848 \pm 11.63 \mathrm{a}$ & $0.210 \pm 0.056 \mathrm{abc}$ & $0.044 \pm 0.006 \mathrm{bcd}$ & $1005 \pm 293 \mathrm{~d}$ \\
$10 \% \mathrm{SS}+\mathrm{Zn} 1+\mathrm{Cd} 1$ & $789 \pm 28.13 \mathrm{bc}$ & $0.227 \pm 0.038 \mathrm{a}$ & $0.068 \pm 0.011 \mathrm{a}$ & $1777 \pm 271 \mathrm{bc}$ \\
$10 \% \mathrm{SS}+\mathrm{Zn} 1+\mathrm{Cd} 2$ & $771 \pm 23.02 \mathrm{~cd}$ & $0.220 \pm 0.047 \mathrm{ab}$ & $0.048 \pm 0.004 \mathrm{bcd}$ & $2046 \pm 296 \mathrm{~b}$ \\
$10 \% \mathrm{SS}+\mathrm{Zn} 2+\mathrm{Cd} 1$ & $828 \pm 7.05 \mathrm{a}$ & $0.191 \pm 0.039 \mathrm{abcd}$ & $0.051 \pm 0.015 \mathrm{bc}$ & $2818 \pm 874 \mathrm{a}$ \\
$10 \% \mathrm{SS}+\mathrm{Zn} 2+\mathrm{Cd} 2$ & $820 \pm 9.54 \mathrm{ab}$ & $0.207 \pm 0.034 \mathrm{abcd}$ & $0.047 \pm 0.004 \mathrm{bcd}$ & $1440 \pm 233 \mathrm{~cd}$ \\
\hline$* \mathrm{~b}, \mathrm{~d} \cdot \mathrm{Statistically} \mathrm{significant} \mathrm{mean}$ differences are indicated
\end{tabular}

*a,b,c,d,e: Statistically significant mean differences are indicated with different letters in the same column $(\mathrm{p}<0.05)$.

$\mathrm{Zn}$ as a metal component of SOD and as an inhibitor of NADPH-oxidase preserves cell membranes from damage by $\mathrm{O}_{2}{ }^{*-}$ radicals (Hajiboland, 2000). $\mathrm{Zn}$ containing SOD (Cu, $\mathrm{Zn}$-SOD)and catalase enzymes activity reduced in insufficient $\mathrm{Zn}$ content in plants. However, under Zn sufficient condition, oxidative stress was alleviated with the enzymatic defence mechanism including SOD, GR, APX (Cakmak, 2000). In a similar study under Cd toxicity conditions, Fe applications influenced SOD enzyme activity in lettuce (Canal and Bozkurt, 2017; Canal and Bozkurt, 2018). The experiment conducted with tomato under $\mathrm{Cd}$ stress conditions demonstrated that anti-oxidative enzyme activities were associated with Zn levels (Cherif et al., 2011). Rizwan et al. (2017) found that the application of Zn-lysine (Zn-lys) complex caused an increase in SOD, APX, CAT and POD enzyme activities in wheat plant under cadmium stress.

\subsection{Cd and $\mathrm{Zn}$ contents in different parts of lettuce}

The application of $10 \% \mathrm{SS}$ alone did not increase $\mathrm{Cd}$ content compared to the control due to low $\mathrm{Cd}$ content of SS. However $10 \% \mathrm{SS}+\mathrm{Cd} 1$ and $10 \% \mathrm{SS}+\mathrm{Cd} 2$ applications increased $\mathrm{Cd}$ content in shoot and root compared to the control. In $10 \% \mathrm{SS}+\mathrm{Cd} 1$ treatment, root $\mathrm{Cd}$ content was 8,65 times higher than shoot $\mathrm{Cd}$ content. In the $10 \% \mathrm{SS}+\mathrm{Cd} 2$ treatment, root $\mathrm{Cd}$ content was 8,0 times higher than shoot $\mathrm{Cd}$ content (Table 5). Generally, $\mathrm{Cd}$ content reduced in the following order roots> stems $>$ leaves (Zhao et al 2011). 10\% SS $+\mathrm{Zn} 1+\mathrm{Cd} 1$ application decreased $\mathrm{Cd}$ content in shoot compared to $10 \% \mathrm{SS}+\mathrm{Cd} 1$ application. $10 \% \mathrm{SS}+\mathrm{Zn} 2+\mathrm{Cd} 2$ application decreased $\mathrm{Cd}$ content in shoot 
compared to $10 \% \mathrm{SS}+\mathrm{Cd} 2$ application (Table 5). $10 \% \mathrm{SS}+\mathrm{Zn} 1$ and $10 \% \mathrm{SS}+\mathrm{Zn} 2$ applications increased $\mathrm{Zn}$ content compared to the control in root and shoot. $10 \% \mathrm{SS}+\mathrm{Zn} 1+\mathrm{Cd} 2$ and $10 \% \mathrm{SS}+\mathrm{Zn} 2+\mathrm{Cd} 2$ applications increased $\mathrm{Zn}$ content compared to $10 \% \mathrm{SS}+\mathrm{Cd} 2$ treatment in root and shoot (Table 5). This result indicated that $\mathrm{Zn}$ treatments increased $\mathrm{Zn}$ and decreased cadmium uptake in different plant parts of lettuce. In the growing environment with $\mathrm{Cd}, \mathrm{Zn}$ application reduces the $\mathrm{Cd}$ concentration in the above-ground parts of the lettuce plant and also reduces the transport from the roots to the upper organs. Cd concentration is higher in the root region of lettuce. It is thought that cadmium accumulates more in roots as a plant defence mechanism. In a similar study, Rajapaksha and Amarakoon, (2011) found that the presence of $\mathrm{Zn}$ decreased $\mathrm{Cd}$ accumulation in shoots of lettuce. $\mathrm{Zn}$ and $\mathrm{Cd}$ with a common transfer membrane protein go into the root cell. Many investigators have suggested that $\mathrm{Zn}$ inhibits Cd uptake (Sharma and Agrawal, 2006; Benakova et al., 2017). However Green et. al. (2017) reported that $\mathrm{Zn}$ did not have an impact on Cd uptake in root and translocation to shoot in rice. Zareet. al. (2018) reported that $\mathrm{Cd}$ : $\mathrm{Zn}$ ratio was to be very important in cadmium uptake by lettuce plant. Results were consistent with the previous studies reportingan antagonistic relationship between $\mathrm{Zn}$ and Cd (Cakmak, 2000; Zhao et al., 2005; Murtaza et al., 2017).

Table 5. Effects of SS, Cd (50,100 $\left.\mathrm{mg} \mathrm{kg}^{-1}\right)$ and $\mathrm{Zn}\left(250,500 \mathrm{mg} \mathrm{kg}^{-1}\right)$ applications on $\mathrm{Cd}$ and $\mathrm{Zn}$ contents of lettuce

\begin{tabular}{lcccl}
\hline Applications & \multicolumn{2}{c}{$\mathrm{Cd}\left(\mathrm{mg} \mathrm{kg}^{-1}\right)$} & \multicolumn{1}{c}{${\mathrm{Zn}\left(\mathrm{mg} \mathrm{kg}^{-1}\right)}^{\text {Root }}$} \\
\hline & \multicolumn{1}{c}{ Shoot } & Root & Shoot & \multicolumn{1}{c}{ R } \\
\hline Control & $0.10 \pm 0.026 \mathrm{e}$ & $0.47 \pm 0.026 \mathrm{e}$ & $39.5 \pm 1.81 \mathrm{~g}$ & $97.8 \pm 15.0 \mathrm{gh}$ \\
$10 \% \mathrm{SS}$ & $0.19 \pm 0.039 \mathrm{e}$ & $0.84 \pm 0.036 \mathrm{e}$ & $76.7 \pm 5.85 \mathrm{e}$ & $170.6 \pm 9.37 \mathrm{f}$ \\
$10 \% \mathrm{SS}+\mathrm{Cd} 1$ & $114.0 \pm 3.55 \mathrm{c}$ & $985.9 \pm 8.91 \mathrm{~d}$ & $61.3 \pm 1.64 \mathrm{f}$ & $109.1 \pm 5.62 \mathrm{~g}$ \\
$10 \% \mathrm{SS}+\mathrm{Cd} 2$ & $186.3 \pm 1.32 \mathrm{a}$ & $1487 \pm 18.82 \mathrm{~b}$ & $56.7 \pm 0.44 \mathrm{f}$ & $85.7 \pm 3.21 \mathrm{~h}$ \\
$10 \% \mathrm{SS}+\mathrm{Zn} 1$ & $0.84 \pm 0.076 \mathrm{e}$ & $5.81 \pm 0.128 \mathrm{e}$ & $162.8 \pm 5.83 \mathrm{~b}$ & $485.2 \pm 6.31 \mathrm{c}$ \\
$10 \% \mathrm{SS}+\mathrm{Zn} 2$ & $0.57 \pm 0.051 \mathrm{e}$ & $3.15 \pm 0.098 \mathrm{e}$ & $217.7 \pm 7.28 \mathrm{a}$ & $822.1 \pm 13.80 \mathrm{a}$ \\
$10 \% \mathrm{SS}+\mathrm{Zn} 1+\mathrm{Cd} 1$ & $103.3 \pm 0.863 \mathrm{~d}$ & $1070.1 \pm 8.98 \mathrm{c}$ & $119.2 \pm 2.00 \mathrm{~d}$ & $384.1 \pm 5.02 \mathrm{~d}$ \\
$10 \% \mathrm{SS}+\mathrm{Zn} 1+\mathrm{Cd} 2$ & $180.9 \pm 3.59 \mathrm{ab}$ & $1654 \pm 36.51 \mathrm{a}$ & $122.3 \pm 3.35 \mathrm{~d}$ & $339.6 \pm 8.83 \mathrm{e}$ \\
$10 \% \mathrm{SS}+\mathrm{Zn} 2+\mathrm{Cd} 1$ & $119.8 \pm 14.22 \mathrm{c}$ & $1057 \pm 13.42 \mathrm{c}$ & $150.8 \pm 2.28 \mathrm{c}$ & $554.9 \pm 25.60 \mathrm{~b}$ \\
$10 \% \mathrm{SS}+\mathrm{Zn} 2+\mathrm{Cd} 2$ & $178.5 \pm 1.995 \mathrm{~b}$ & $1499 \pm 27.92 \mathrm{~b}$ & $164.0 \pm 5.69 \mathrm{~b}$ & $491.8 \pm 8.71 \mathrm{c}$ \\
\hline
\end{tabular}

*a,b,c,d,e: Statistically significant mean differences are indicated with different letters in the same column $(\mathrm{p}<0.05)$.

\subsection{Cd and Zn content of experimental soil}

$10 \% \mathrm{SS}$ alone application did not increase DTPA-Cd compared to the control due to low $\mathrm{Cd}$ content of SS. However $10 \% \mathrm{SS}+\mathrm{Cd} 1$ and $\mathrm{Cd} 2$ applications increased DTPA-Cd content compared to the control. $10 \% \mathrm{SS}+\mathrm{Zn}+\mathrm{Cd} 1$ application decreased DTPA-Cd content compared to Cd1 alone application. Similarly in $10 \% \mathrm{SS}$ amended growth medium, increased $\mathrm{Zn}$ application with $\mathrm{Cd} 2$ decreased DTPA-Cd content compared to $\mathrm{Cd} 2$ alone application (Table 6). A reduction of the extractable $\mathrm{Zn}$ in soil by the application of $\mathrm{Cd}$ may be due to the exchange of $\mathrm{Zn}$ by $\mathrm{Cd}$ from soil sorption sites and non-absorbable complexes in the soil solution (Kabata-Pendias, 2010).

$10 \%$ SS alone application increased DTPA-Cd compared to the control due to high Cd content of SS. Increased levels of $\mathrm{Zn}$ application with $\mathrm{Cd} 1$ increased DTPA-Zn content compared to $\mathrm{Cd} 1$ alone. Similarly, increased levels of $\mathrm{Zn}$ application with $\mathrm{Cd} 2$ application increased DTPA-Zn content compared to $\mathrm{Cd} 2$ alone (Table 6 ).We found that $10 \% \mathrm{SS}+\mathrm{Zn}$ applications with $\mathrm{Cd}$ reduced $\mathrm{Cd}$ concentration and increased $\mathrm{Zn}$ concentration in soil. Köleli et al. (2004) reported that $\mathrm{Cd}$ application in $\mathrm{Zn}$ deficient soil reduced $\mathrm{Zn}$ uptake in wheat, whereas the application of $\mathrm{Cd}$ to soil with adequate $\mathrm{Zn}$ did not reduce $\mathrm{Zn}$ uptake in wheat. The decrease in grain $\mathrm{Cd}$ concentration by $\mathrm{Zn}$ application in $\mathrm{Cd}$-contaminated and uncontaminated soil might be due to the antagonistic effect of $\mathrm{Zn}$ (Saifullah et al., 2014). 
Table 6. Effects of SS, Cd (50,100 $\left.\mathrm{mg} \mathrm{kg}^{-1}\right)$ and Zn (250, $\left.500 \mathrm{mg} \mathrm{kg}^{-1}\right)$ applications on DTPA- Cd and $\mathrm{Zn}$ contents of soil

\begin{tabular}{lll}
\hline Applications & $\mathrm{Cd}\left(\mathrm{mg} \mathrm{kg}^{-1}\right)$ & $\mathrm{Zn}\left(\mathrm{mg} \mathrm{kg}^{-1}\right)$ \\
\hline Control & $0.012 \pm 0.001 \mathrm{~g}$ & $1.65 \pm 0.034 \mathrm{i}$ \\
$10 \% \mathrm{SS}$ & $0.043 \pm 0.001 \mathrm{~g}$ & $6.72 \pm 0.19 \mathrm{~h}$ \\
$10 \% \mathrm{SS}+\mathrm{Cd} 1$ & $109.8 \pm 1.31 \mathrm{~d}$ & $12.45 \pm 0.56 \mathrm{~g}$ \\
$10 \% \mathrm{SS}+\mathrm{Cd} 2$ & $202.5 \pm 5.51 \mathrm{a}$ & $12.02 \pm 0.15 \mathrm{~g}$ \\
$10 \% \mathrm{SS}+\mathrm{Zn} 1$ & $0.075 \pm 0.024 \mathrm{~g}$ & $66.1 \pm 1.79 \mathrm{e}$ \\
$10 \% \mathrm{SS}+\mathrm{Zn} 2$ & $0.133 \pm 0.092 \mathrm{~g}$ & $114.4 \pm 1.08 \mathrm{a}$ \\
$10 \% \mathrm{SS}+\mathrm{Zn} 1+\mathrm{Cd} 1$ & $93.6 \pm 1.15 \mathrm{e}$ & $63.83 \pm 0.82 \mathrm{f}$ \\
$10 \% \mathrm{SS}+\mathrm{Zn} 1+\mathrm{Cd} 2$ & $196.7 \pm 1.17 \mathrm{~b}$ & $67.56 \pm 1.074 \mathrm{~d}$ \\
$10 \% \mathrm{SS}+\mathrm{Zn} 2+\mathrm{Cd} 1$ & $86.8 \pm 4.95 \mathrm{f}$ & $104.36 \pm 0.92 \mathrm{~b}$ \\
$10 \% \mathrm{SS}+\mathrm{Zn} 2+\mathrm{Cd} 2$ & $165.6 \pm 4.51 \mathrm{c}$ & $93.53 \pm 0.95 \mathrm{c}$ \\
\hline
\end{tabular}

*a,b,c,d,e: Statistically significant mean differences are indicated with different letters in the same column $(\mathrm{p}<0.05)$.

\section{Conclusion}

According to these results, the low cadmium content of the used sewage sludge did not cause toxic effects. However, $10 \% \mathrm{SS}+\mathrm{Cd}$ applications had significant toxicity effects in the lettuce plant. However, $10 \% \mathrm{SS}+\mathrm{Zn}$ applications along with $\mathrm{Cd}$ was found to decrease soil $\mathrm{Cd}$ concentrations and increase $\mathrm{Zn}$ availability. It was found that this situation reduced $\mathrm{Cd}$ uptake in lettuce plant and resulted in an improvement of yield criteria. Anti-oxidative enzyme activity, particularly SOD and GPX enzymes, increased with $\mathrm{Zn}$ applications under $10 \% \mathrm{SS}+\mathrm{Cd}$ conditions. These results indicate that a $10 \% \mathrm{SS}+\mathrm{Zn}$ application could be beneficial for ameliorating the toxic effects of $\mathrm{Cd}$ in lettuce.

\section{Reference}

Anonymous, (2010). T.C. Official Journal of Soil Pollution Control Regulation No: 27605, Ankara.

Abbas, M.S., Akmal, M., Ulah, S Hassan \& MU Farooq, S. (2017). Effectiveness of zinc and gypsum application against cadmium toxicity and accumulation in wheat (Triticumaestivum L.). Commun Soil Sci Plan, 48, 1659-1668.

Aravind, P., Narasimha, M., \& Prasad, V. (2005). Modulation of cadmium-induced oxidative stress in Ceratophyllumdemersum by zinc involves ascorbate-glutathione cycle and glutathione metabolism. Plant Physiol Bioch, 43, 107-116.

Benakova, M., Ahmadi, H., Ducaiova, Z., Tylova, E., Clemens, S. \& Tuma, J. (2017). Effects of Cd and $\mathrm{Zn}$ on physiological and anatomical properties of hydroponically grown Brassica napus plants. Environ Sci Pollut Control Ser, 24, 20705-20716.

Benavides, M.P., Gallego, S.M., \& Tomaro, M.L. (2005). Cadmium toxicity in plants.Braz J Plant Physiol, 17, 21-34.

Beutler, E. (1984). Red Cell Metabolism: A Manual of Biochemical Methods. Thirth Edition. ed. Orlando, FL: Grune and Startton.

Bouyoucous, G.D. (1951). A recalibration of the hydrometer method for making mechanical analysis of soil. Soil Agron J, 43, 434-438.

Cakmak, I. (2000). Possible roles of zinc in protecting plant cells from damage by reactive oxygen species. New Phytol, 146 (2), 185-205.

Canal-Boysan, S., \& Bozkurt, M.A. (2017). Effects of iron application against cadmium toxicity on growth and anti-oxidative enzyme activity in lettuce. Fresen Environ, 26(4), 2614-2620.

Canal-Boysan, S., \& Bozkurt, M.A. (2018). Kadmiyum toksisitesine karşı demir gübrelemesi ve arıtma çamurunun marul (Lactucasativa L. var .longifolia) bitkisinin gelişimine ve antioksidatif enzim aktivitesine etkisi. YYÜ TAR BIL DERG, 28(1), 19-26.

Castro, E., Manas, P., \& De las Heras, J. (2009). A comparison of the application of different waste products to a lettuce crop: Effects on plant and soil properties. Science Horticulturae, 123, $148-155$. 
Chaoui, A., Mazhoudi, S., Ghorbal, M.H., \& El Ferjani, E. (1997). Cadmium and zinc induction of lipid peroxidation and effects on antioxidant enzyme activities in bean (Phaseolus vulgaris L). Plant Sci, 127 (2), 139-147.

Cherif, J., Mediouni, C., Ammar, W.B., \& Jemal, F. (2011). Interactions of zinc and cadmium toxicity in their effects on growth and in antioxidative systems in tomato plants (Solarium lycopersicum). J Environ Sci-China, 23, 837-844.

Düzgüneş, A., Kesici, O.T., Kavuncu, O., \& Gürbüz, F. (1987). Araşttrmave Deneme Metodları (İstatistik Metodlarl-II). Ank. Üniversitesi Ziraat Fakültesi Yayınları, Ankara.

Erdogan, R., Zaimoglu, Z., Budak, F.,\& Koseoglu, C. (2011). Use of sewage sludge in growth media for ornamental plants and its effects on growth and heavy metal accumulation. J. Food Agric Environ, 9, 632-635.

Fhole, L., \& Günzler, W.A. (1984). Assays of Glutathione Peroxidase. Method Enzymol 105, 114-121.

Grant, C.A., Buckley, W.T., Bailey, L.D., \& Selles, F. (1998). Cadmium accumulation in crops. Can J Plant Sci, 78, 1-17.

Green, C.E., Chaney, R.L., \& Bouwkamp, J., (2017). Increased zinc supply does not inhibit cadmium accumulation by rice (Oryza sativa L.). J Plant Nutr, 40, 869-877.

Gülser, F., \& Sönmez, F. (2012). Cadmium effects on potassium content and pepper seedling growth in different peat ratios. Eurasian Soil Sci, 2, 110-115.

Hana, S., Rachid, R., Ibtissem, S., Houria, B., \& Mohammed-Reda, D. (2008). Induction of antioxidative enzymes by cadmium stress in tomato (Lycopersicon esculentum). Afr J Plan Sci, $2(8), 72-76$.

Hajiboland, R. (2000). Zinc efficiency in rice (Oryzasativa L.) plants. Ph.D dissertation: Verlag Grauer, Stuttgart. Hohenheim University. Stuttgart, Germany: Verlag Grauer.

Hassan, M.J., Zhang, G., Wu, F., Wei, K., \& Chen, Z. (2005). Zinc alleviates growth inhibition and oxidative stress caused by cadmium in rice. J Plant Nutr Soil SC, 168, 255-261.

Hizalan, E., \& Ünal, E. (1966). Topraklarda Önemli Analizler, Ankara Üniversitesi Ziraat Fakültesi Yayınları, Ankara.

Hossain, M.K., Strezov, V.,\& Nelson, P.F. (2015). Comparative assessment of the effect of wastewater sludge biochar on growth, yield and metal bioaccumulation of cherry tomato. Pedosphere, 25, 680-685.

Jackson, M.L. (1958). Soil Chemical Analysis Prentice Hall, Inc., Prentice Hall, Inc.

Jibril, S.A., Hassan, S.A., Ishak, C.F., \& Wahab, P.E.M. (2017). Cadmium toxicity affects phytochemicals and nutrient elements composition of lettuce (Lactucasativa L.). Hindawi Advances in Agri, 2017, 1-7.

Kabata-Pendias, A., \& Pendias, H. (1984). Trace Elements in Soils and Plants., FL: CRC Press.

Kabata-Pendias, A. (2010). Trace elements in soils and plants, CRC Press.

Kacar, B. (1994). Bitki ve Toprağın Kimyasal Analizleri: III Toprak Analizleri, A.Ü.Z. Eğitim Araștırma ve Geliștirme Vakfı Yayınları, Ankara.

Kacar, B., \& Katkat, V.N. (1999). Gübreler ve Gübreleme Tekniği, Uludağ Üniversitesi Güçlendirme Vakfi Yayınları, Ankara.

Köleli, N., Eker, S., \& Cakmak, I. (2004). Effect of zinc fertilization on cadmium toxicity in durum and bread wheat grown in zinc-deficient soil. Environ Pollut, 131(3), 453-459.

Lin, Y.F., \& Aarts, M.G.M. (2012). The molecular mechanism of zinc and cadmium stress response in plants.Cell Mol Life Sci, 69 (19), 3187-3206.

Liu, H.J., Zhang, J.L., Christie, P., \& Zhang, F.S. (2008). Influence of iron plaque on uptake and accumulation of Cd by rice (Oryzasativa L.) seedlings grown in soil. Sci Total Environ, 394, 361-368.

Mannervik, B., \& Guthenberg, C. (1981). Glutathione transferase (human placenta). Academic Press, 77, 231-235.

McCord, J.M., \& Fridovich, I. (1969). Superoxide dismutase an enzymic function for erythrocuprein (hemocuprein). J Biol Chem, 244 (22), 6049-6055.

Mckenna, I.M., Chaney, R.L., \& Williams, F.M. (1993). The effects of cadmium and zinc interactions on the accumulation and tissue distribution of zinc and cadmium in lettuce and spinach. Environ Pollut, 79 (2), 113-120. 
Monteiro, M.S., Santos, C., Soares, A.M.V.M., \& Mann, R.M. (2009). Assessment of biomarkers of cadmium stress in lettuce. Ecotox Environ Safe, 72 (3), 811-818.

Murtaza, G., Javed, W., Hussain, A., Qadir, M., \& Aslam, M. (2017). Soil-applied zinc and copper suppress cadmium uptake and improve the performance of cereals and legumes. Int $J$ Phytoremediat, 19 (2), 199-206.

Rajapaksha, R.M.C.P., \& Amarakoon, I.D. (2011). Response of Lettuce and Rhizosphere Biota to Successive Additions of Zinc and Cadmium to a Tropical Entisol. Commun Soil Sci Plan, 42 (11), 1336-1348

Rizwan, M., Ali, S., Hussain, A., Ali, Q., Shakoor, M.B., Zia-ur-Rehman, M., Farid, M., \& Asma, M. (2017). Effect of zinc-lysine on growth, yield and cadmium uptake in wheat (Triticumaestivum L.) and health risk assessment. Chemosphere, 187, 35-42.

Saifullah, N., Sarwar, M., Bibi, S., Ahmad, M., \& Ok, Y.S. (2014). Effectiveness of zinc application to minimize cadmium toxicity and accumulation in wheat (Triticum aestivum L.). Environ Earth Sci, 71 (4), 1663-1672.

Sharma, R.K., \& Agrawal, M. (2006). Single and combined effects of cadmium and zinc on carrots: Uptake and bioaccumulation. J Plant Nutr, 29 (10), 1791-1804.

Shahabivand, S., \& Aliloo, A.A. (2016). Piriformospora indica promotes growth and antioxidant activities of wheat plant under cadmium stress. YYÜ TAR BILL DERG, 26 (3), 333-340.

Tran, T.A., \& Popova, L.P. (2013). Functions and toxicity of cadmium in plants: recent advances and future prospects. Turk J Bot, 37 (1), 1-13.

Viehweger, K. (2014). How plants cope with heavy metals. Bot Stud 55.

Walkley, A. (1947). A critical examination of a rapid method for determining organic carbon in soils - effect of variations in digestion conditions and of inorganic soil constituents. Soil Sci, 63 (4), 251-264.

Wu, F.B., \& Zhang, G.P. (2002). Alleviation of cadmium-toxicity by application of zinc and ascorbic acid in barley. $J$ Plant Nutr, 25 (12), 2745-2761.

Zare, A., Khoshgoftarmanesh, A., Malakouti, M., Bahrami, H.,\& Chaney, R.(2018). Root uptake and shoot accumulation of cadmium by lettuce at various $\mathrm{Cd}$ : $\mathrm{Zn}$ ratios in nutrient solution. Ecotoxicol. Environ.Saf., 148, 441-446.

Zhao, A.Q., Tian, X.H., Lu, W.H., Gale, W.J., Lu, X.C., \& Cao, Y.X. (2011). Effect of Zinc on Cadmium Toxicity in Winter Wheat. J Plant Nutr, 34 (9-11), 1372-1385.

Zhao, Z.Q., Zhu, Y.G., Kneer, R., \& Smith, S.E. (2005). Effect of zinc on cadmium toxicity-induced oxidative stress in winter wheat seedlings. J Plant Nutr, 28(11), 1947-1959. 